Jurnal Penelitian dan Pengabdian Kepada Masyarakat Bidang ilmu Pendidikan

\title{
Pengembangan Aplikasi Pembelajaran Pengenalan Huruf Hijaiyah Pada Tingkatan Sekolah Dasar Menggunakan Macromedia Flash
}

\author{
Supriyaddin' $^{1}$, M. Nur Imansyah ${ }^{2}$, Leni Meilani ${ }^{3}$ \\ 1,2 Dosen Program Studi Pendidikan Teknologi Informasi, STKIP Yapis Dompu \\ ${ }^{3}$ Mahasiswa Program Studi Pendidikan Teknologi Informasi, STKIP Yapis Dompu \\ E-mail: supriyaddin2000@gmail.com
}

Article History: Received: 2020-09-14 || Revised: 2020-10-02 || Published: 2020-10-26

Sejarah Artikel : Diterima: 2020-09-14 || Direvisi: 2020-10-02 || Dipublikasi: 2020-10-26

\begin{abstract}
Research has been carried out by developing a learning application for hijaiyah letter recognition at the elementary school level using macromedia flash with the aim of facilitating the delivery of material about Hijaiyah. The data were analyzed descriptively quantitative-qualitative with the results: media experts obtained an eligibility percentage of $77.5 \%$, material experts $80 \%$, teacher responses $96 \%$, pre-test questions $49.2 \%$, and post-test items $77.7 \%$ and the total percentage Feasibility is $380.4 \%$ with an average value percentage of $76 \%$, which is on a scale of $61 \%-80 \%$ in the feasible category. The conclusion of this research is that the application of learning hijaiyah letter recognition at the elementary school level using macromedia flash is suitable for use as a teaching aid.
\end{abstract}

Keywords: Development; Worthiness ; Macromedia Flash.

\begin{abstract}
Abstrak
Telah dilakukan penelitian dengan mengembangkan aplikasi pembelajaran pengenalan huruf hijaiyah pada tingkatan sekolah dasar menggunakan macromedia flash dengan tujuan mempermudah penyampaian materi tentang Hijaiyah. Data dianalisis secara deskriptif kuantitatif-kualitatif dengan hasil: ahli media memperoleh persentase kelayakan $77,5 \%$, ahli materi $80 \%$, respon guru $96 \%$, soal pre test $49,2 \%$, dan soal post test $77,7 \%$ serta jumlah keseluruhan persentase kelayakan adalah 380,4\% dengan persentase nilai rata-rata sebesar $76 \%$ yaitu berada pada skala 61\%-80\% dengan kategori layak. Simpulan penelitian ini adalah aplikasi pembelajaran pengenalan huruf hijaiyah pada tingkatan sekolah dasar menggunakan macromedia flash layak digunakan sebagai alat bantu dalam mengajar.
\end{abstract}

Kata kunci: Pengembangan; Kelayakan; Macromedia Flash.

\section{PENDAHULUAN}

Menurut UU Sisdiknas Nomor 20 tahun 2003, memaparkan bahwa pendidikan merupakan suatu usaha yang dilakukan secara sadar dan terencana untuk mewujudkan suasana dan proses pembelajaran agar peserta didik secara aktif dan mampu mengembangkan potensi yang ada didalam dirinya untuk memiliki kekuatan spiritual keagamaan, kepribadian yang baik, pengendalian diri, berahlak mulia, cerdas dan keterampilan yang diperlukan oleh dirinya dan masyarakat. Senada dengan Peraturan Pemerintah Nomor 19 tahun 2005 pasal satu tentang Standar Nasional juga mendefinisikan bahwa Pendidikan adalah kriteria minimal tentang sistem pendidikan di seluruh wilayah hukum Negara Kesatuan Republik Indonesia. Hal ini sejalan dengan Permendikbud nomor 65 tahun 2013 tentang Standar Proses Pendidikan Dasar dan Menengah yaitu pada prinsip pembelajaran nomor 13 menjelaskan bahwa proses pembelajaran akan lebih efisien dan efektif dengan pemanfaatan komputer sebagai media pembelajaran. 
Perkembangan teknologi informasi juga sangat mempengaruhi dunia pendidikan yang mempersiapkan generasi penerus pembangunan bangsa yang berkualitas dalam intelektual maupun akhlak. Hal ini terlihat dari penggunaan teknologi dalam bidang pendidikan dan ditetapkannya kurikulum pembelajaran yang menekankan pada penguasaan siswa terhadap teknologi informasi (Kusumawati, Setiyani, 2017). Pengajaran membaca hijaiyah biasanya dilakukan melalui sistem mengaji atau belajar membaca Al-Qur'an di masjid, sekolah atau di rumah. Belajar dengan sistem mengaji ini biasanya dilakukan dalam waktu yang relatif lama bahkan terkadang sampai bertahun-tahun, keadaan seperti ini bagi kita sudah dianggap suatu hal yang wajar mengingat bahwa belajar huruf-huruf Arab itu adalah suatu hal yang sulit karena bahasa Arab adalah termasuk bahasa asing yang mempunyai bentuk serta bunyi yang berbeda dengan bahasa Indonesia, selain dari itu untuk mempelajari tanda baca atau ilmu tajwidnya saja di perlukan waktu yang tidak sedikit (Ariyadi, 2010). Lama waktu yang dibutuhkan untuk belajar membaca hijaiyah menimbulkan rasa malas bagi orang yang akan mempelajarinya (Ratnawati, 2011). Salah satunya bagi siswa sekolah dasar. Pada saat kelas dua mereka akan diajarkan materi hijaiyah, dengan waktu yang singkat yaitu dua semester. Dalam waktu yang cukup singkat, belum tentu siswa mengenal dan menghafal huruf hijaiyah apalagi dengan metode pembelajaran yang konvensional. Siswa akan merasa bosan dan jenuh dengan kegiatan belajar mengajar yang hanya menggunakan poster dan papan tulis sebagai media dalam mengajar. Media pembelajaran baru dengan memanfaatkan teknologi komputer diharapkan dapat mengatasi kejenuhan tersebut, dengan membuat suatu aplikasi pembelajaran hijaiyah menggunakan macromedia flash diharapkan dapat memberikan banyak tampilan-tampilan gambar yang menarik dan mudah dipahami.

Berdasarkan hasil observasi awal yang dilakukan pada tanggal 19 September 2019 di Madrasah Ibtidaiyah AL-MUTAHIRIN, peneliti menemukan bahwa dalam mengajar materi hijaiyah guru menggunakan poster hijaiyah dan papan tulis sebagai media dalam mengajar dan berdasarkan hasil wawancara dengan guru yang mengajar materi hijaiyah menyatakan bahwa, materi hijaiyah masuk pada mata pelajaran Qur'an Hadist. Dalam mengajar hijaiyah masih menggunakan poster hijaiyah dan papan tulis sebagai media dalam mengajar dan tidak pernah menggunakan media lain seperti aplikasi komputer.

\section{METODE PENELITIAN}

Model pengembangan dapat berupa model prosedural, model konseptual dan model teoretik. Adapun model pengembangan pada penelitian ini adalah model prosedural. Selain itu, model pengembangan pada penelitian ini mengikuti, Model pengembangan dapat berupa model prosedural, model konseptual dan model teoretik. Adapun model pengembangan pada penelitian ini adalah model prosedural. Selain itu, model pengembangan pada penelitian ini mengikuti prosedur penelitian dan pengembangan menurut Sugiyono (2009) yang terdiri dari sepuluh tahap. Sepuluh tahap tersebut dapat dilihat pada gambar berikut:

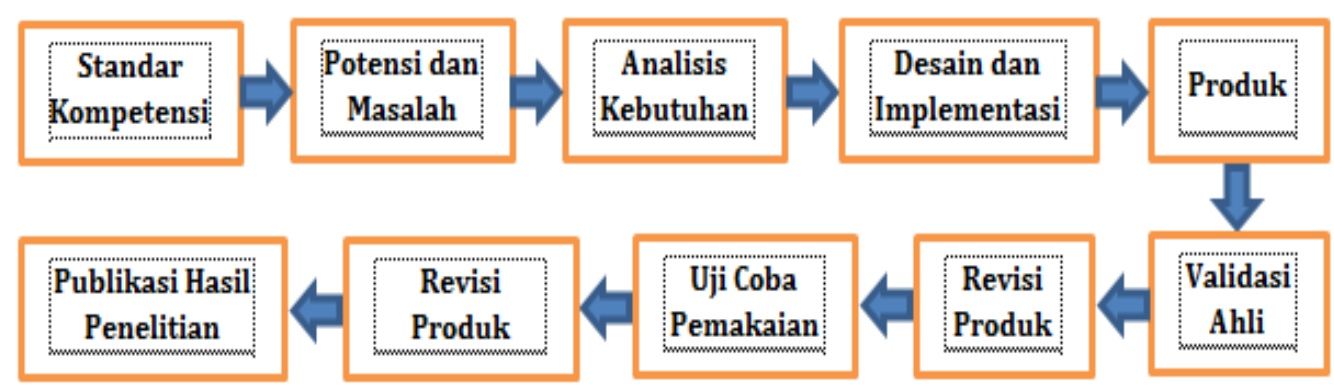

Gambar 1. Model pengembangan R \& D 
Adapun jenis data yang digunakan pada penelitian ini adalah data kuantitatif yang berasal dari penilaian para ahli dan pengisian angket produk serta Pre test dan Post test. Peneliti selanjutnya menyusun teknik analisis data. Teknik analisis data adalah suatu cara untuk mengolah sebuah data menjadi informasi sehingga karakteristik data tersebut menjadi mudah untuk dipahami.

1. Mengetahui kelayakan aplikasi pembelajaran pengenalan huruf hijahiyah pada penerapannya di dunia pendidikan.

Untuk menganalisis kelayakan produk, peneliti menggunakan presentasi kelayakan untuk mengukur pendapat ahli, dan guru yang menilai media pembelajaran tersebut. Jawaban setiap item instrumen yang menggunakan skala likert mempunyai gradasi dari sangat positif sampai sangat negatif. Adapun rumus yang digunakan untuk mengetahui produk tersebut layak atau tidak adalah sebagai berikut:

$$
\text { Persentase Kelayakan }=\frac{\text { Jumlah Skor Yang Didapat }}{\text { Jumlah Skor Yang Diharapkan }} X 100 \%
$$

Pembagian kategori kelayakan hanya dengan memperhatikan rentang bilangan persentase. Pembagian persentase kelayakan 100\% dibagi rata-rata lima kategori sesuai dengan jumlah skala likert (Arikunto, 2009). Pembagian persentase kelayakannya adalah sebagai berikut:

Tabel 1. Kategori kelayakan

\begin{tabular}{|l|l|}
\hline Interval Persentase & Nilai \\
\hline$<21 \%$ & Sangat Tidak Layak \\
\hline $21 \%-40 \%$ & Tidak Layak \\
\hline $41 \%-60 \%$ & Cukup Layak \\
\hline $61 \%-80 \%$ & Layak \\
\hline $81 \%-100 \%$ & Sangat Layak \\
\hline
\end{tabular}

2. Siswa dapat mengucapkan huruf-huruf hijaiyah, membedakan huruf-huruf hijaiyah, dan membedakan tanda baca.

Untuk mengetahui apakah siswa sudah dapat mengucapkan huruf-huruf hijaiyah, membedakan huruf-huruf hijaiyah, dan membedakan tanda baca, maka dilakukan evaluasi pembelajaran dengan menggunakan teknik pengumpulan data tes. Pada teknik ini, peneliti menggunakan soal pre test dan post test. Adapun rumus yang digunakan untuk menentukan kemampuan siswa sebelum dan sesudah diterapkan aplikasi pembelajaran adalah sebagai berikut:

$$
\text { Persentase Kelayakan }=\frac{\text { Jumlah Skor Yang Didapat }}{\text { Jumlah Skor Yang Diharapkan }} X 100 \%
$$

\section{HASIL DAN PEMBAHASAN}

\section{A. Analisis Hasil Uji Ahli Media}

Analisis hasil uji ahli media adalah suatu analisis yang dilakukan setelah memperoleh data penilaian produk dari ahli media berupa tanda centang pada pilihan jawaban sangat setuju, 
setuju, ragu-ragu, tidak setuju dan sangat tidak setuju sehingga data tersebut di olah untuk mengetahui kelayakan produk. Proses analisis data dapat di lihat di bawah ini.

Tabel 2. Distribusi Data Angket validasi Ahli Media

\begin{tabular}{|c|c|c|c|c|c|}
\hline No & Skala & Kategori & Frekuensi & Skor & Jumlah \\
\hline 1 & $0 \%-20 \%$ & Sangat Tidak Layak & - & 1 & - \\
\hline 2 & $21 \%-40 \%$ & Tidak Layak & - & 2 & - \\
\hline 3 & $41 \%-60 \%$ & Cukup Layak & 5 & 3 & 15 \\
\hline 4 & $61 \%-80 \%$ & Layak & 8 & 4 & 32 \\
\hline 5 & $81 \%-100 \%$ & Sangat Layak & 3 & 5 & 15 \\
\hline & Jumlah Soal & & $\mathbf{1 6}$ & & $\mathbf{6 2}$ \\
\hline
\end{tabular}

Adapun pada tabel distribusi data angket validasi ahli media terdiri dari skala, kategori, frekuensi, skor dan jumlah skor. Pada skala berisi penilaian dimulai dari angka persentase 0\%$20 \%$ dengan kategori sangat tidak layak frekuensi tidak ada skor 1 dan jumlah skor tidak ada. Pada skala 21\%-40\% dengan kategori tidak layak frekuensi tidak ada skor 2 dan jumlah skor tidak ada, Skala 41\%-60\% dengan kategori cukup layak frekuensi sebanyak 5 skor 3 dan jumlah skor 15. Skala 61\%-80\% dengan kategori layak frekuensi sebanyak 8 skor 4 dan jumlah skor 32, dan skala 81\%-100\% dengan kategori sangat layak, frekuensi sebanyak 3 skor 5 dan jumlah skor 15. Adapun rata-rata jumlah skor sebanyak 62. Dari uraian tersebut skala yang paling banyak frekuensinya adalah skala 61\%-80\% dengan kategori layak.

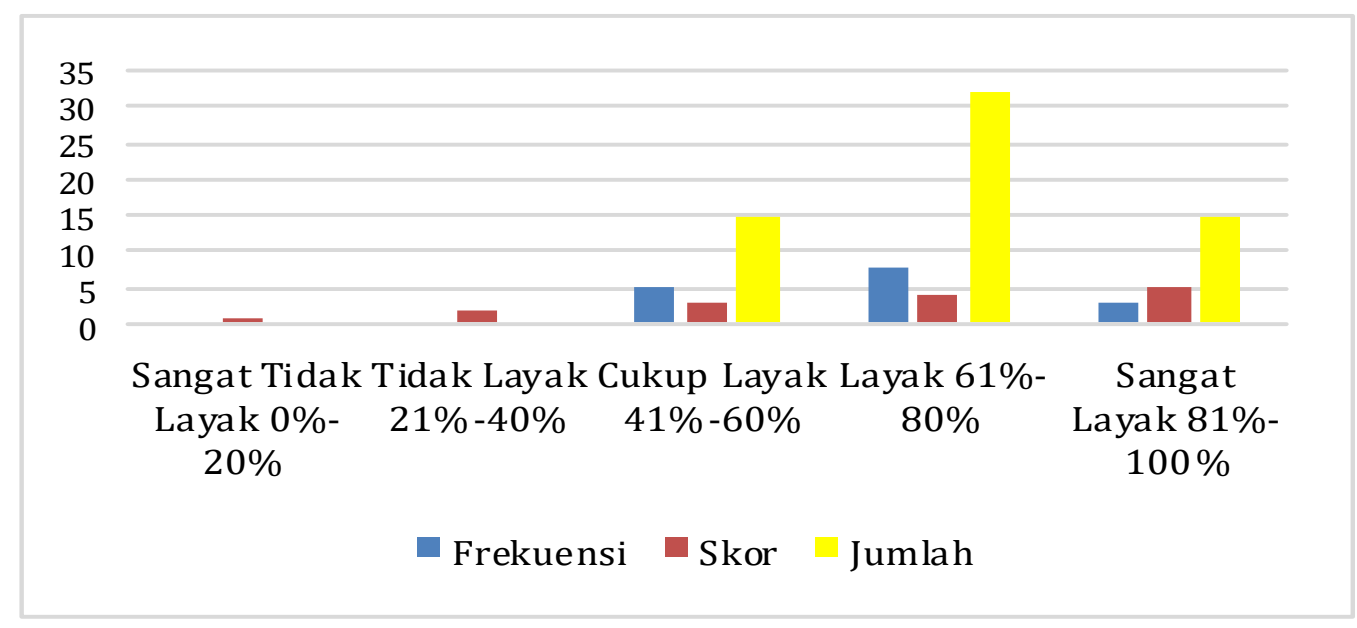

Gambar 2. Diagram frekuensi analisis angket validasi ahli media

Dari grafik batang di atas frekuensi yang paling tinggi terletak pada kategori layak dengan skala 61\%-80\%. Dari hasil analisis data di atas dapat disimpulkan bahwa hasil analisis data ahli media terhadap Aplikasi Pembelajaran Hijaiyah dikatakan layak dengan persentase kelayakan $77,5 \%$.

\section{B. Analisis Hasil Uji Ahli Materi}

Analisis hasil uji ahli materi adalah suatu analisis yang dilakukan setelah memperoleh data penilaian produk dari ahli materi berupa tanda centang pada pilihan jawaban sangat setuju, setuju, ragu-ragu, tidak setuju dan sangat tidak setuju sehingga data tersebut di olah untuk mengetahui kelayakan produk. Proses analisis data dapat dilihat sebagai berikut. 
Tabel 3. Distribusi Data Angket validasi Ahli Materi

\begin{tabular}{|c|c|c|c|c|c|}
\hline No & Skala & Kategori & Frekuensi & Skor & Jumlah \\
\hline 1 & $0 \%-20 \%$ & Sangat Tidak Layak & - & 1 & - \\
\hline 2 & $21 \%-40 \%$ & Tidak Layak & - & 2 & - \\
\hline 3 & $41 \%-60 \%$ & Cukup Layak & - & 3 & - \\
\hline 4 & $61 \%-80 \%$ & Layak & 12 & 4 & 60 \\
\hline 5 & $81 \%-100 \%$ & Sangat Layak & - & 5 & - \\
\hline \multicolumn{2}{|r}{ Jumlah Soal } & $\mathbf{1 2}$ & & $\mathbf{6 0}$ \\
\hline
\end{tabular}

Skala penilaian di mulai dari angka persentase 0\%-20\% dengan kategori sangat tidak layak frekuensi tidak ada skor 1 dan jumlah skor tidak ada. Pada skala 21\%-40\% dengan kategori tidak layak, frekuensi tidak ada skor 2 dan jumlah skor tidak ada, skala 41\%-60\% dengan kategori cukup layak frekuensi tidak ada skor 3 dan jumlah skor tidak ada, skala 61\%-80\% dengan kategori layak frekuensi sebanyak 12 skor 4 dan jumlah skor 60, dan skala 81\%-100\% dengan kategori sangat layak, frekuensi tidak ada, skor 5 dan jumlah skor tidak ada. Adapun rata-rata jumlah skor sebanyak 60 . Dari uraian tersebut, skala yang paling banyak frekuensinya adalah skala 61\%-80\% dengan kategori layak.

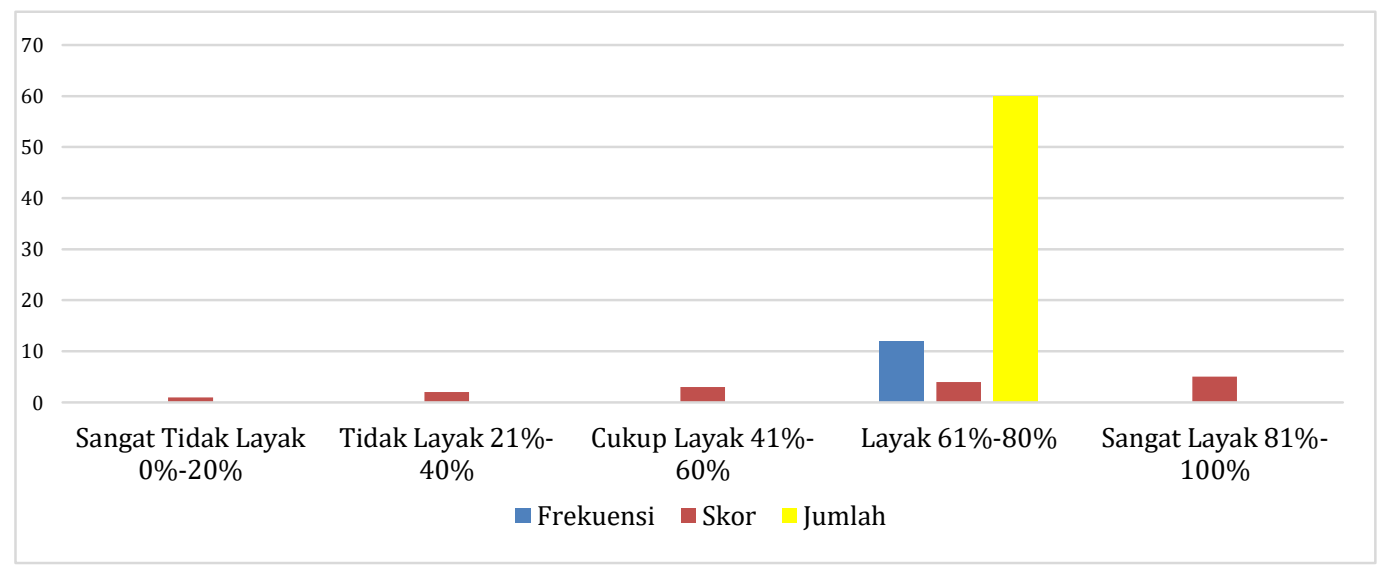

Gambar 3. Diagram frekuensi analisis angket validasi ahli materi

Berdasarkan hasil analisis data yang didapatkan dari angket validasi ahli materi dan setelah diolah pada rumus persentase kelayakan, maka diperoleh nilai sebesar $80 \%$. Sehingga aplikasi pembelajaran hijaiyah tersebut dikatakan layak.

\section{Analisis Hasil Uji Coba Soal Pre Test dan Post Test Siswa}

Analisis hasil uji coba soal pre test dan post test adalah suatu analisis yang dilakukan sesudah mendapatkan data hasil jawaban soal pre test dan post test dengan membagikan soal pilihan ganda sebanyak 10 butir soal kepada siswa sebelum dan sesudah menerapkan aplikasi pembelajaran huruf hijaiyah. Proses analisis data dapat dilihat di bawah ini.

Tabel 4. Distribusi data hasil uji coba soal pre test

\begin{tabular}{|c|c|c|c|c|}
\hline No & Skala & Kategori & Frekuensi & Keterangan \\
\hline 1 & $0 \%-20 \%$ & Sangat Tidak Layak & 1 & \\
\hline 2 & $21 \%-40 \%$ & Tidak Layak & 5 & \\
\hline 3 & $41 \%-60 \%$ & Cukup Layak & 5 & \\
\hline 4 & $61 \%-80 \%$ & Layak & 2 & \\
\hline 5 & $81 \%-100 \%$ & Sangat Layak & 0 & \\
\hline \multicolumn{2}{|r|}{ Jumlah Siswa } & $\mathbf{1 3}$ & \\
\hline
\end{tabular}


Distribusi data angket jawaban hasil uji coba soal pre test pada skala 0\%-20\% frekuensi sebanyak 1, skala $21 \%-40 \%$ frekuensi sebanyak 5, skala 41\%-60\% frekuensi sebanyak 5, skala 61\%-80\% frekuensi sebanyak 2, dan skala $81 \%-100 \%$ frekuensi tidak ada. Setelah dianalisis menggunakan rumus persentase kelayakan dengan perolehan nilai kelayakan 49,2\% yaitu masuk kategori cukup layak dengan skala $41 \%-60 \%$.

Tabel 5. Distribusi data hasil uji coba soal post test

\begin{tabular}{|c|c|c|c|c|}
\hline No & Skala & Kategori & Frekuensi & Keterangan \\
\hline 1 & $0 \%-20 \%$ & Sangat Tidak Layak & 0 & \\
\hline 2 & $21 \%-40 \%$ & Tidak Layak & 0 & \\
\hline 3 & $41 \%-60 \%$ & Cukup Layak & 4 & \\
\hline 4 & $61 \%-80 \%$ & Layak & 3 & \\
\hline 5 & $81 \%-100 \%$ & Sangat Layak & 6 & \\
\hline \multicolumn{7}{r|}{ Jumlah Siswa } & $\mathbf{1 3}$ & \\
\hline
\end{tabular}

Adapun pada tabel distribusi jawaban hasil uji coba soal post test pada skala $0 \%-20 \%$ frekuensi tidak ada, skala 21\%-40\% frekuensi tidak ada, skala $41 \%-60 \%$ frekuensi sebanyak 4 , skala 61\%-80\% frekuensi sebanyak 3, dan skala 81\%-100\% 6. Setelah di analisis menggunakan rumus persentase kelayakan dengan perolehan nilai kelayakan $77,7 \%$ yaitu masuk pada kategori layak dengan skala 61\%-80\%. Berdasarkan hasil analisis data jawaban soal pre test dan post test dapat disimpulkan bahwa nilai persentase jawaban soal post test siswa lebih tinggi dibanding persentase jawaban soal pre test siswa.

\section{Hasil Uji Coba Ahli Media, Ahli Materi, Respon Guru, dan Hasil Uji Coba Soal Pre test dan Post Test}

Tabel 6. Distribusi hasil uji coba ahli media, ahli materi, respon guru, dan hasil uji coba soal pre test dan post test

\begin{tabular}{|c|l|c|}
\hline No & \multicolumn{1}{|c|}{ Validator } & Persentase kelayakan \\
\hline 1 & Ahli Media & $77,5 \%$ \\
\hline 2 & Ahli Materi & $80 \%$ \\
\hline 3 & Respon Guru & $96 \%$ \\
\hline 4 & Soal Pre Test & $49,2 \%$ \\
\hline 5 & Soal Post Test & $77,7 \%$ \\
\hline \multicolumn{2}{|r|}{ Jumlah } & $\mathbf{3 8 0 , 4}$ \\
\hline \multicolumn{2}{|r|}{ Nilai Rata-rata } & $\mathbf{7 6 \%}$ \\
\hline
\end{tabular}

Adapun pada tabel hasil uji coba ahli media, ahli materi, dan respon guru, serta hasil uji coba soal pre test dan post test berupa persentase kelayakan. Ahli media memperoleh persentase kelayakan $77,5 \%$, ahli materi $80 \%$, respon guru $96 \%$, soal pre test $49,2 \%$, dan soal post test $77,7 \%$ serta jumlah keseluruhan persentase kelayakan dari validator adalah 380,4\% dengan persentase nilai rata-rata sebesar 76\% yaitu berada pada kategori layak skala 61\%-80\%.

\section{SIMPULAN DAN SARAN}

\section{A. Simpulan}

Berdasarkan hasil penelitian yang telah dilakukan, maka dapat disimpulkan bahwa aplikasi pembelajaran pengenalan huruf hijaiyah pada tingkatan sekolah dasar masuk pada kategori layak dengan persentase nilai sebesar $76 \%$. 


\section{B. Saran}

Berdasarkan hasil penelitian yang telah dilakukan, salah satu saran yang dapat dikemukakan oleh peneliti yaitu diharapkan guru dapat menggunakan aplikasi pengenalan huruf hijaiyah pada tingkatan sekolah dasar menggunakan macromedia flash untuk mempermudah penyampaian materi tentang huruf hijaiyah agar menjadi daya tarik siswa sehingga mampu meningkatkan pengetahuan, keterampilan dan motivasi belajar.

\section{DAFTAR RUJUKAN}

Arikunto, S. (2009). Prosedur Penelitian Suatu Pendekatan Praktik. Edisi Revisi 6. Jakarta : Rineka Cipta.

Ariyadi. (2010). Belajar Membaca Al-Qur'an Tanpa Pengenalan Huruf Hijaiyah (Penerapan Metode Al-Qur'an Quantum System (QQS) di SD Muhammadiyah Miliran Yogyakarta). Skripsi tidak terpublikasi. Yogyakarta. Universitas Islam Negeri Sunan Kalijaga.

Departemen Pendidikan Nasional. (2003). Undang-Undang RI No. 20 tahun 2003. Tentang Sistem Pendidikan Nasional. Jakarta: Depdiknas.

Departemen Pendidikan Nasional. (2005). Peraturan Pemerintah Nomor 19 Tahun 2005. Tentang Standar Nasional Pendidikan. Jakarta: Depdiknas.

Kemendikbud. (2013). Permendikbud Nomor 65 Tahun 2013. Tentang Standar Proses Pendidikan Dasar dan Menengah. Jakarta: Kemendikbud.

Kusumawati, Setiyani. (2017). Aplikasi Pembelajaran Iqro Berbasis Multimedia Pada TK Islam Terpadu Al Mubarak Palu. Jurnal Elektronik Sistem Informasi dan Komputer. Vol.3. No.1. Januari-Juni. 2017.

Ratnawati. (2011). Aplikasi Alat Bantu Ajar Hijaiyah Berbasis Multimedia Menggunakan Macromedia Flash. Skripsi tidak terpublikasi. Yogyakarta. Universitas Negeri Yogyakarta.

Sugiyono. (2009). Metode Penelitian Kuantitatif, Kualitatif dan R\&D. Bandung : Alfabeta. 